УДК 371.31:316.614

DOI: $\underline{10.35619 / \text { iiu.v1i11.270 }}$

Oleksandr Fedoryshyn

Candidate of Pedagogical Sciences, Professor at Practice of English Language Department, Rivne State University for the Humanities,

Rivne, Ukraine

ORCID: 0000-0003-0731-0186

e-mail: ofedoryshin@gmail.com

\title{
SOCIALIZATION IN THE SCHOOLING PROCESS VIA COOPERATIVE LEARNING
}

\begin{abstract}
The article discusses the importance of understanding how the built environment of schools relates to the socialization process of students. School can be effective systems that promote social, emotional and academic skills of children and can foster motivation. School has become a primary agency of socialization. It is the first large-scale organization of which the child becomes a member and which reflects what is going on in the wider society. Modern school is facing a challenge of creating the educational environment in a modern form which develops both academic and necessary learning skills, allowing looking for what is needed in future work cases. These skills include the ability to recognize and manage emotions, develop feelings of respect and care for others, build positive relationships, make responsible decisions and cope with various challenges. The school's potential for socialization lies in the amount of times students spend in school and in activities related to the school. During this time the students acquires much from their teachers and fellow students.

To enhance achievement and socialization among students cooperative learning can be used as an effective teaching strategy. It is a social construction where knowledge is negotiated and acquired through social interaction rather than being transmitted by the teacher. Cooperative learning is suitable to promote a social construction of knowledge, mutual learning, personal and social development. It requires students to work in small groups in order to make possible face-to-face interactions between members. Effectiveness of cooperative learning is that every member of the group is involved in the learning process obtaining the experience of interaction. It represents situations in which teachers structure group work with the aim to maximize both social and cognitive outcomes. Consequently, cooperative learning methods can notably improve the process of socialization of students in school.
\end{abstract}

Key words: socialization, social skills, society, education, agents of socialization, cooperative learning, team work, interaction, group processing, positive interdependence.

Problem statement. Socialization is the process through which people are taught to be proficient members of a society. It describes the ways that people come to understand societal norms and expectations, to accept society's beliefs, and to be aware of societal values. It also describes the way people come to be aware of themselves and to reflect on the suitability of their behaviour in their interactions with others. Socialization occurs as people engage and disengage in a series of roles throughout life. Each role, like the role of son or daughter, student, friend, employee, etc., is defined by the behaviour expected of a person who occupies a particular position. 
The studies and reviews by researchers confirm that cooperative learning is an effective teaching strategy that can be used to enhance achievement and socialization among students and contribute to improved attitudes towards learning and working with others, including a better understanding of students from diverse cultural backgrounds. Cooperative learning is defined as a group learning activity organized so that learning is dependent on the socially structured exchange of information between learners in groups, in which each learner is held accountable for his or her own learning, and is motivated to increase the learning of others. Motivation plays an important role in the development of social skills and the facilitation of interactions between peers and in academic success particularly.

Cooperative learning is a social construction where knowledge is negotiated and acquired through social interaction rather than being transmitted by the teacher. This view acknowledges the importance of interaction, peer mediation, and scaffolding. After a look at some approaches in education, based on the positive outcomes that some research studies have shown in terms of cognitive, personal, and social development, we consider that cooperative learning is suitable to promote a social construction of knowledge, mutual learning, and at the same time, personal and social development. By working together, students are involved in supportive environments that promote interaction and scaffolding, they get the basis for interacting, practicing different teamwork skills, taking active part in the learning process, and taking responsibility for their learning.

Research publications. Socialization has been described as the process by which individuals learn and adopt the knowledge, skills, values, attitudes and expectations of a group in a particular community or organization. Socialization allows all individuals in a community to develop very similar values, norms and beliefs (O'Neil, 2009). Socialization is a lifelong process, though the early stages of it are crucial (Shepard, 2009, p. 90).

Education is the most significant factor of socialization. Through education the individual learns the fundamental sense of the cultural and social world. The school is like a miniature society where the child's personal development takes place. The socialization functions in education can be defined as availability for work and an ability to make decisions independently so that the individual in his later life period could perform his social roles and integrate in social structures with specific role types. Socialization can be more accurately defined as "the process whereby people acquire the rules of behaviour and systems of beliefs and attitudes that equip a person to function effectively as a member of a particular society" (Durkin, 1995b, p. 614). Ordinarily, this process occurs naturally as children take part in "daily routines which immerse them directly in the values of their community" (Durkin, 1995b, p. 618). Furthermore, children themselves actively participate in the process as they interact with others in a reciprocal way and as they form their own unique understanding of the Social world around them (Bandura, 1986; Durkin, 1995a, 1995b; Goodnow, 1990; Ruble, 1987).

Cooperative learning is considered to be one of the most effective ways of socialization at school. Cooperative learning has received a lot of attention and praise especially since the 1990s. More than 70 major studies in ISA by federally sponsored research centres, field-initiated investigations and local districts examining their own practices have demonstrated cooperative learning's effectiveness on a range of outcomes. John Dewey, American philosopher, psychologist, and educational reformer, one of the most prominent American scholars in the first half of the twentieth century, believed it was important that students develop knowledge and social skills that could be used outside of the classroom. He continually argued that education and learning are social and interactive processes, and thus the school itself is a social institution through which social 
reform can and should take place (Dewey, 1938). Another scholar Lewin Kurt also greatly influenced upon American education, especially with regard to a pedagogical practice known as "cooperative learning". Lewin's approach to cooperative learning was based on the ideas of establishing relationships between group members in order to successfully carry out and achieve the learning goal (Sherman, L.W., Schmuck, R., Schmuck, P., 2006). "Cooperative learning has its greatest effects on student learning when groups are recognized or rewarded based on the individual learning of their group members" (Slavin, 1996, p. 52). "Cooperative learning is based on two theories: Structure - Process Outcome theory and Social Interdependence theory (Johnson D., Johnson R., 1998).

Thus, the research aim and objectives is to underline the importance of using widely cooperative learning in the process of student socialization.

Presenting the main research material. Social integration, or the process through which individuals are included in the economic, political and social fabric of society, differs by life course stages, with each stage broadly characterized by different channels of integration. Socialization is a process where person learns about role, status and value that should have in society. Socialization is not the same as socializing (interacting with others, like family, friends and co-workers); to be precise, it is a sociological process that occurs through socializing. Without socialization it is impossible to learn nonmaterial culture of society, such as its beliefs, values and norms. Most importantly, it helps to understand the natural and social worlds in which we live. It is a lifelong process through which we become prepared for new social environments and expectations in every stage of our lives.

There are six agents of socialization: family, school, peer group, mass media, workplace, religion. A basic activity of human association in any social group or community, regardless of size is education whereby people gain knowledge, acquire understanding, master skills or internalize values. The school is an artificial institution set up for the purpose of socialization and cultural transmission. It is the first large-scale organization of which the child becomes a member and which reflects what goes on in the wider society. Students spend the major part of their active hours of the day in school. Obviously, during this time they acquire a lot from their teachers and fellow students. The school is the next to the family in terms of importance as far as socialization is concerned and combines the formal and informal approaches in its socializing function.

1. The school in a formal way provides the child with:

- knowledge of basic intellectual skills such as reading, writing, verbal expression, quantitative and other cognitive abilities. Education teaches languages and allows people communicate with each other according to positions in society.

- cultural achievements of one's society

- opportunities to acquire social and vocational abilities which are necessary in order to make one a social, useful and economically productive member of the society

- gender roles as perceived as suitable roles by the society;

2. Educational systems socialize students to become members of society, to play meaningful roles in the complex network of independent positions;

3. Education helps in shaping values and attitudes to the needs of the contemporary society;

4. Education widens the mental horizons of students and teaches them new ways of looking at themselves and their society;

5. Education offers young people opportunities for intellectual, emotional and social growth. Thus education can be influential in promoting new values and stimulating adaptation of changing conditions; 
6. Informally and especially through social clubs, the school enables the child to learn a number of other social roles and skills which are also important for his/ her overall development as a member of society. For example:

- education teaches the laws, traditions and norms of the community, the rights that individuals will enjoy and the responsibilities that they will undertake;

- education teaches how one is to behave toward his/ her playmates and adults;

- education teaches how to share things and ideas;

- education teaches how to compete responsibly;

- schooling teaches how to cooperate;

- schooling instills the community's pattern of respect; thus how to relate to others well and obey rules;

- schooling enables one to intendise the culture of one's society;

- education leads toward tolerant and humanitarian attitudes. For example, college graduates are expected to be more tolerant than high school graduates in their attitudes toward ethnic and social groups.

5 types of socialization are distinguished:

1. Primary socialization. It is a process in which people learn attitudes, values and actions appropriate to individuals as members of a particular culture.

2. Secondary socialization. It refers to process of learning on what is appropriate behaviour as a member of a smaller group within the larger society.

3. Developmental socialization. It is the process of learning behaviour in a social institution or developing social skills.

4. Anticipatory socialization. It refers to the mental rehearsals, concrete plans and subtle changes in values and perceptions that a significant change in social roles is about to occur.

5. Re-socialization. It refers to the process of discarding former behaviour patterns and accepting new ones as part of a transition in one's life. This occurs throughout the human life (Sherman, L. W., Schmuck, R., \& Schmuck, P., 2006).

Cooperative learning provides an excellent opportunity to acquire social skills while participants work in groups, improve their oral communicational skills and go beyond the linguistic aspect promoting better relationships and having a better classroom atmosphere, and this process is developed simultaneously. Through interaction and group work students discover ways of being on task, supporting each other, and learning in a meaningful way. Cooperative learning represents situations in which teachers structure group work with the aim to maximise both social and cognitive outcomes.

According to Johnson and Johnson the five elements of cooperative learning are:

1. Positive interdependence: students work toward a common goal. They fail or succeed together as a whole group.

2. Individual accountability: each student in the group is assessed individually. Students learn together so they perform higher individually.

3. Face-to-face promotive interaction: students promote each other's learning by assisting, supporting, encouraging and praising each other's efforts to achieve.

4. Social skills: interpersonal and small group skills such as leadership, decisionmaking, trust-building, communication and conflict-management, need to be taught.

5. Group processing: group members discuss effectiveness of group. What went well, what needs improvement and how well they maintained an effective working relationship (Johnson \& Johnson, 1999, pp. 67-73).

Cooperative learning requires students to work in small teams, usually from two to five learners, in order to make possible individualized face-to-face interactions between members. The team is supposed to engage in a real group task, which requires 
contribution from all members rather than a single individual. Thus, cooperative learning requires teachers to introduce and structure both positive interdependence and individual accountability.

Positive goal interdependence is crucial, as it allows learners to clearly perceive that their goal is positively linked to the goal of their partners. Learners must identify a common goal and become aware of their complementarity in achieving their goal, that is, they must realize that they can reach their goal if the other team members also reach it. Positive interdependence requires that teachers give a clear task to the team and structure positive goal interdependence. Teachers should also introduce individual responsibility to make sure that the contribution of all members in a team is possible, necessary and that individual learning is visible. The common goal of the team must be to ensure that every member understands, masters, and integrates the materials on which the team is working. (Halpern, D.F.)

Canada can be a good example in solving the problem of socialization in practice. Canadian government pays great attention to the rich cultural diversity that exists among Canada's native aboriginal indigenous, native, First Nations people. Schools socialize children by teaching them about citizenship and national pride. They require classes about Canadian history and geography. Textbooks are continually scrutinized and revised to update attitudes toward the different cultures in the country as well as perspectives on historical events; thus, children are socialized to a different national or world history. Recent textbook editions include information about the mistreatment of First Nations which more accurately reflects those events than in textbooks of the past. In this regard, schools educate students explicitly about aspects of citizenship important for being able to participate in a modern, heterogeneous culture.

According to OECD (Organization for Economic co-operation and Development) statistics most Canadian children spend about seven hours a day and 180 days a year in school, which makes it hard to deny the importance school has on their socialization. In elementary and junior high, compulsory education amounts to over 8,000 hours in the classroom. Students are not only in school to study math, reading, science and other subjects - the manifest function of this system. Schools also serve a latent function in society by socializing children into behaviours like team work, following a schedule and using textbooks.

School and classroom rituals, led by teachers serving as role models and leaders, regularly reinforce what society expects from children. Sociologists describe this aspect of schools as the hidden curriculum, the informal teaching done by schools. The latent functions of competition, teamwork, classroom discipline, time awareness and dealing with bureaucracy are features of the hidden curriculum.

In addition, a Canadian high school is offering "adulting" classes to teach students life skills that will help them in the future. In Grade 12 students are finally one year away from being able to enter into the real world and they quickly find out they don't know anything about it. After graduation many of them find that their Algebra and History skills don't really prepare them for the real world of budgeting and taxes. That's why E.J. Lajeunesse High School in Windsor (Ontario) is now offering "adult classes" to teach the students life skills that they will need after they leave the world of the public school system. The school is taking the right steps to ensure that their students won't feel lost in the adult world when they graduate and move forward in their lives. More than 100 of their students are currently taking courses and learning life skills to be prepared for being an adult.

One of the skills that this high school is focusing on teaching their students is financial planning. This includes mandatory skills such as how to budget and how to maintain your 
credit cards. Another important skill is cooking for one. The students learn a variety of easy cooking skills. Home maintenance and car maintenance are also other adult skills that the students are learning. Things like how to patch a hole in the drywall, use power tools, check your car oil, and change a tire are important skills that every adult should conquer before they go and live on their own. Clothing is also another important topic when it comes to finally being forced to be an adult. How to sort your laundry, iron your interview skirts and sew on a new button are all skills that you are going to need once you can't pawn off all your laundry on your mother anymore. Finally, E.J. Lajeunesse High School is also teaching their students how to manage stress. It is known, that moving into the adult world directly after high school can be stressful and it is important to discover ways to make this stress more bearable. This approach gives young people the opportunity to learn the skills they need in order to be self-sufficient, successful adults from the moment they leave home. (Howse, 2019)

Conclusions and further research prospects. Schools can be effective systems that promote the social, emotional and academic skills of children and youth by serving as social microcosms of the broader society. It is widely recognized among education researchers and practitioners that social and emotional (non-cognitive) skills significantly influence student learning and performance. These skills include recognizing and managing emotions, developing caring and concern for others, establishing positive relationships, making responsible decisions and handling challenging situations constructively. These skills include serve as the foundation for a broad range of psychosocial, academic and occupational outcomes. Subsequently, many primary and secondary schools should invest resources into interventions that focus on the promotion of these skills.

There is evidence to suggest that the built environment of schools affects these social and emotional conditions and contributes to student socialization - factors that promote social and emotional skills - associated with academic learning and performance. The teacher's task is to create the possibility to foster and construct a safe and supportive environment in the classroom where the students could feel confident to express their ideas and respect others without fear or rejection. Through interaction and group work students discover ways of being on task supporting each other and learning in a meaningful way. Social skills gained in the classroom are lifelong skills.

Thus, schools must focus educational process on training useful citizens who will obediently confirm to society's norms and will accept the role and status that society will confer upon them when they have finished their schooling. Socialization in school will help young people to function successfully in their social worlds.

O'Neil, D. (2009). Socialization. URL: https://www.ukessays.com/essays/sociology/the-importance-of-socialization.php (Accessed 23/12/20)

Shepard, J. M. (2009). Sociology. Cengage Learning. Inc. USA., 640 p.

Durkin, K. (1995b). Socialization. In A.S.R. Manstead \& M. Hewstone (Eds.), The Blackwell encyclopedia of social psychology. Cambridge, MA: Basil Blackwell, p. 614618.

Durkin, K. (1995a). Developmental social psychology: From infancy to old age. Cambridge, Mass: Blackwell, 834 p.

Bandura, A. (1986). Social foundations of thought and action: A social cognitive theory. Englewood Cliffs, NJ: Prentice-Hall, 617 p. 
Goodnow, J. (1990). The socialization of cognition. In J. Stigler, R. Schweder, \& G. Herdt (Eds.), Cultural Psychology: Essays on Comparative Human Development (p. 259286). Cambridge: Cambridge University Press. doi:10.1017/CBO9781139173728.008

Ruble, D. N. (1987). The acquisition of self-knowledge: A self-socialization perspective. In N. Eisenberg (Ed.), Contemporary topics in developmental psychology. New York: Wiley., pp. 281-312

Dewey, John (1938). Experience \& Education. New York, NY: Kappa Delta Pi.

Sherman, L. , Schmuck, R., \& Schmuck, P. (2006). Kurt Lewin's contribution to the theory and practice of education in the United States: The importance of cooperative learning. In (Janusz Trempala, Albert Pepitone \& Bertram H. Raven, editors) Lewinian Psychology. Procedings of the International Conference Kurt Lewin: Contribution "to contemporary psychology”. Bydgoszcz, Poland: Kazimier Wielki University Press, p 191-207.

URL: http://www.users.miamioh.edu/shermalw/EDP621SM2006/sherman_schmuck-polandlewin2006.pdf (Accessed 16/01/20)

Slavin, R. (1996). Research on Cooperative Learning and Achievement: What We Know, What We Need to Know. Contemporary Educational Psychology, 21, 43-69. http://dx.doi.org/10.1006/ceps.1996.0004 (Accessed 16/01/20)

Johnson, D., \& Johnson, R. (1999). Making Cooperative Learning Work. Theory Into Practice, 38(2), 67-73. URL: www.jstor.org/stable/1477225(Accessed 17/01/20)

Lewis, B. (2019). Cooperative Learning: Definition and Examples - Thought Co: URL: https://www.thoughtco.com/what-is-cooperative-learning-2081641(Accessed 24/121/19)

Howse, A. (2019). A Canadian High School Is Finally Offering “Adulting” Classes To Teach Students Life Skills. Narcity. URL: https://www.narcity.com/news/ca/on/adulting-classes-are-now-being-offered-at-thisontario-high-school-to-teach-their-students-life-skills (Accessed 16/01/20)

Halpern, D. (2011). Creating Cooperative Learning Environments. American Psychological Society. URL: https://www.psychologicalscience.org/uncategorized/creating-cooperative-learningenvironments.html (Accessed 16/01/20)

Bremer, C. \& Smith J. (2004). Teaching social skills. National Center on Secondary Education and Transition: Information Brief. URL: http://www.ncset.org/publications/viewdesc.asp?id=1749 (Accessed 16/01/20)

Buchs, Céline \& Butera, Fabrizio. (2015). Cooperative learning and social skills development. URL: https://www.researchgate.net/publication/ 272197928_Cooperative_learning_and_social_skills_development (Accessed 24/12/19)

David W. Johnson \& Roger T. Johnson (November 5th 2018). Cooperative Learning: The Foundation for Active Learning, Active Learning - Beyond the Future, Sílvio Manuel Brito, IntechOpen, DOI: 10.5772/intechopen.81086.URL: https://www.intechopen.com/books/active-learning-beyond-the-future/ cooperativelearning-the-foundation-for-active-learning (Accessed 24/12/19)

Little, W. (2014). Introduction to Sociology - 1st Canadian Edition. Victoria, B.C.: BCcampus. https://opentextbc.ca/introductiontosociology/(Accessed 24/02/20)

Siegel, C. (2005). Implementing a research-based model of cooperative learning. The journal of educational research, 98(6), 339-349.

Robson, K. Sociology of Education in Canada. - Chapter 6. Socialization in the Schooling Process. Retrieved on January 27, 2020 from https://ecampusontario.pressbooks.pub/robsonsoced/chapter/_unknown__6/ (Accessed 27/01/20) 


\title{
СОЦІАЛІЗАЦЯ У ШКІЛЬНІЙ ОСВІТІ ЗАСОБАМИ КООПЕРАТИВНОГО НАВЧАННЯ
}

\author{
Олександр Федоришин \\ кандидат педагогічних наук, \\ професор кафедри практики англійської мови \\ Рівненського державного гуманітарного університету. \\ м. Рівне, Україна \\ ORCID: 0000-0003-0731-0186 \\ e-mail: ofedoryshin@gmail.com
}

Анотація. У статті обговорюється важливість соціалізації учнів в умовах сучасних викликів. Питання полягає в тому, як створити відповідне середовище, яке максимально навчить їх адаптуватися до дорослого життя 3 найменшими труднощами. Соціалізація - це процес, через який вони вчаться бути повноцінними членами суспільства, а школа з її потенціалом є найважливішим агентом після сім’ї, де цей процес відбувається. Адже більшість активного часу учні проводять у школі і дізнаються багато від вчителів та однокласників. Сучасна школа знаходиться перед викликом: як створити безпечне навчальне середовище, яке сприятиме формуванню і розвитку як академічних, так і соціальних навичок учнів, і які дозволять їм досягнути успіхів у своїх майбутніх починаннях. Ці навички включають уміння розпізнавати емоції та управляти ними, розвивати почуття поваги і турботи по стосовно інших, налагоджувати позитивні стосунки, приймати відповідальні рішення та справлятися з різними викликами. Звичайно, головною фігурою в цьому процесі $є$ вчитель.

Кооперативне навчання передбачає роботу учнів у невеликих групах, а ефективність полягає в тому, що кожен член групи є задіяним у процес навчання i отримує досвід взаємодії з іншими. У кооперативному навчанні вчитель виступає посередником і допомагає учням ставати більш самостійними, організовуючи роботу таким чином, щоб пізнавальні і соціальні надбання були найвищими. Кооперативне навчання $є$ соціальною конструкцією. Знання засвоюються швидше у соціальній взаємодії, ніж від вчителя. Підтверджено, що такий підхід максимально сприяє соціалізації знань, умінню працювати і навчатися разом, i, в цілому, індивідуально та соціально розвиватися.

Ключові слова: соціалізація, соціальні навички, суспільства, агенти соціалізації, кооперативне навчання, командна робота, взаємодія, груповий процес, позитивна взаємозалежність.

Стаття надійшла до редакиії 03.03.2020 p. 